Jurnal Visionida, Volume 4 Nomor 2 Desember 2018

\title{
PENGARUH BAURAN PEMASARAN TERHADAP KEPUTUSAN PEMBELIAN PRODUK PERCETAKAN PADA PT. BALEBAT DEDIKASI PRIMA BOGOR
}

\section{THE EFEECT OF MARKETING MIX ON DECISION PURCHASE OF PRINTING PRODUCT IN PT. BALEBAT DEDIKASI PRIMA BOGOR}

\author{
Meida Srikinasih $^{1)}$; Samsuri $^{2)}$ \\ Progam Management Studies Faculty of Economics, University of Djuanda Bogor \\ Email : ${ }_{1 \text { mimameida@gmail.com; samsuri.fe@unida.ac.id }{ }^{2)}}$
}

\begin{abstract}
The research aims to find out consumer responses and the influence of Marketing mix, to the purchase decision of PT Balebat Bogor printing product either simultaneously or partially. The object of research involves people who have made a purchase of 100 respondents to be sampled. This form of research uses verification. Data includes multiple regression, test of determination and significant test simultaneously and pasrsial. The results of this study: 1) Consumer response on the highest purchase decision is product quality; 2) the value of double correlation $R$ of 0.844 means the relationship of Marketing Mix gives a very strong influence; 3$)$ the magnitude of the determination coefficient of $R$ Square value is 0.712, which means that the purchase decision of the society is $71,2 \%$ explained by product quality, pricing, promotion strategy, distribution channel and 28,8\% influenced by other elements not examined by author; The result of research partially and simulty known that Marketing Mix have positive effect also significant in purchasing decision.
\end{abstract}

Keywords: Product, Promotion, Price, Distribution, Purchase Decision

\begin{abstract}
ABSTRAK
Tujuan penelitian untuk mengetahui tanggapan konsumen dan pengaruh bauran pemasaran terhadap keputusan pembelian produk percetakan pada PT. Balebat Bogor, baik simultan ataupun parsial. Objek penelitian melibatkan masyarakat yang pernah melakukan pembelian sejumlah 100 responden untuk dijadikan sampel. Jenis penelitian menggunakan bentuk veritifikatif. Analisis data mencakup regresi berganda, uji determinasi dan uji signifikan secara simultan dan parsial.Hasil penelitian ini adalah : 1) tanggapan konsumen pada keputusan pembelian tertinggi adalah kualitas produk; 2) nilai korelasi ganda $\mathrm{R}$ sebesar 0,844 artinya hubungan bauran pemasaran memberi pengaruh yang sangat kuat; 3) besarnya koefisien determinasi nilai R Square didapatkan 0,712 yang artinya keputusan pembelian masyarakat $71,2 \%$ dijelaskan oleh kualitas produk, penetapan harga ,strategi promosi, saluran distribusi dan $28,8 \%$ dipengaruhi oleh unsur-unsur lain yang tidak diteliti penulis ;4) hasil penelitian secara parsial maupun simultan diketahui bahwa bauran pemasaran berpengaruh positif juga signifikan pada keputusan pembelian.
\end{abstract}

Kata kunci : Produk, Promosi, Harga, Distribusi, Keputusan Pembelian 


\section{PENDAHULUAN}

Dengan adanya kerjasama Masyarakat Ekonomi Asia (MEA), perkembangan industri mengalami perkembangan cukup pesat, sehingga persaingan usaha begitu kuat. MEA cukup berdampak pada persaingan global sehingga peran industri sangat mempengaruhi sektor perekonomian negara. Setiap industri harus membuat strategi yang handal agar mampu meningkatkan pertumbuhan usaha dan memenangkan sebuah persaingan industri. Salah satu industri di Indonesia yang mengalami pertumbuhan cukup pesat yaitu industri percetakan. Pada tahun 2016 Industri percetakan mengalami pertumbuhan sebesar 5,3\%. Angka tersebut tumbuh jika dibandingkan proyeksi pada 2015 dengan nilai $4,7 \%$. Pertumbuhan industri percetakan akan terus mengalami peningkatan bersamaan dengan tumbuhnya industri tinta dan kertas di Indonesia.

Berdasarkan data statistik 2016 penyebaran industri perusahaan percetakan di Indonesia belum merata, jumlah terbanyak terdapat di pulau Jawa yaitu sebesar 73,3\% dari jumlah percetakan di seluruh Indonesia, lalu disusul pulau Sumatra sebesar 13,4\% dan Kalimantan sebesar 5,8\%. Data tersebut menunjukkan bahwa persaingan perusahaan percetakan dominan berada di kepulauan Jawa, yang penyebarannya berada di propinsi Jawa Barat khususnya Jakarta, Bogor, Tanggerang, Depok, Cikarang, Karawang dan
Bekasi. Banyaknya jumlah percetakan di Jawa Barat membuat teknologi percetakan di wilayah tersebut berkembang pesat. Kondisi ini menuntut industri percetakan untuk meningkatkan keunggulan bersaing dalam menarik perhatian serta mempengaruhi pelanggan dalam proses pengambilan keputusan. Pengambilan keputusan konsumen adalah suatu proses di mana konsumen benar-benar bersedia membeli. Kotler (2008:68) menyatakan bahwa keputusan konsumen salah satunya dipengaruhi oleh bauran pemasaran di antaranya adalah produk, harga, promosi dan saluran pendistribusian.

Salah satu perusahaan percetakan di Jawa Barat yaitu PT. Balebat Dedikasi Prima. PT Balebat Dedikasi Prima diresmikan pada 17 Juli 2000 oleh PT.Telkom Indonesia, yang beralamatkan di Jl.Veteran II No.17 Desa Teluk Pinang Kecamatan Ciawi Kabupaten Bogor. Produk yang dihasilkan adalah buku pelajaran, majalah, kalender, agenda kemasan dan lain-lain. Perusahaan tersebut memiliki 116 karyawan dan 891 pelanggan. Beberapa tahun terakhir PT. Balebat mengalami ketidakstabilan jumlah pendapatan penjualan pada setiap periode tahunan. Ketidakstabilan pendapatan tersebut dapat dikarenakan berbagai faktor bauran pemasaran yang mencakup produk, harga, promosi, dan distribusi. Berikut adalah abel penjualan dan realisasi penyelesaian produk perusahaan.

Tabel 1. Data Penjualan dan Realisasi Penyelesaian Produk Perusahaan Percetakan PT Balebat Dedikasi Prima Tahun 2012 - 2016

\begin{tabular}{|c|c|c|c|c|c|c|c|c|c|c|c|}
\hline \multirow[b]{2}{*}{ Tahun } & \multirow[b]{2}{*}{$\begin{array}{l}\text { Jumlah } \\
\text { Customer }\end{array}$} & \multirow[b]{2}{*}{$\begin{array}{l}\text { Harga } \\
\text { Rata2 } \\
\text { Buku }\end{array}$} & \multicolumn{3}{|c|}{ Order Buku } & \multicolumn{4}{|c|}{ Keterlambatan produk } & \multicolumn{2}{|c|}{ Produk Kembali } \\
\hline & & & $\begin{array}{l}\text { Target } \\
\text { penjualan } \\
\text { (exp) }\end{array}$ & $\begin{array}{c}\text { Realisasi } \\
\text { Produk exp }\end{array}$ & $\begin{array}{c}\text { Tingkat } \\
\text { Ketercapaian } \\
(\%)\end{array}$ & $\begin{array}{c}\text { Jumlah } \\
\text { produk } \\
\text { (exp) }\end{array}$ & $\begin{array}{c}\text { Persentase } \\
\text { produk } \\
(\%)\end{array}$ & $\begin{array}{c}\text { Jumlah } \\
\text { (hari) }\end{array}$ & $\begin{array}{c}\text { Persentase } \\
\text { hari }(\%)\end{array}$ & $\begin{array}{c}\text { Jumlah } \\
\text { produk } \\
\text { (exp) }\end{array}$ & $\begin{array}{c}\text { Persentase } \\
\text { kembali } \\
(\%)\end{array}$ \\
\hline 2012 & 674 & 13,000 & $3,000,000$ & $3,808,647$ & 127 & 38,900 & 1 & 18 & 5 & 98,000 & 3 \\
\hline 2013 & 658 & 15,000 & $3,500,000$ & $3,732,984$ & 107 & 102,900 & 3 & 27 & 8 & 189,600 & 5 \\
\hline 2014 & 726 & 11,000 & $4,500,000$ & $3,837,947$ & 85 & 90,000 & 2 & 22 & 6 & 87,600 & 2 \\
\hline 2015 & 549 & 15,000 & $4,500,000$ & $2,259,032$ & 50 & 567,000 & 25 & 52 & 15 & 239,900 & 11 \\
\hline 2016 & 891 & 16,500 & $6,000,000$ & $5,392,045$ & 90 & 98,000 & 2 & 23 & 6 & 98,000 & 2 \\
\hline Total & 3498 & 70,500 & $\begin{array}{c}21,500,00 \\
0\end{array}$ & $19,030,655$ & 459 & 896,800 & 33 & 142 & 40 & 713,100 & 23 \\
\hline $\begin{array}{c}\text { Rata- } \\
\text { rata }\end{array}$ & 699.6 & 14,100 & $4,300,000$ & $3,806,131$ & 92 & 179,360 & 7 & 28 & 8 & 142,620 & 5 \\
\hline
\end{tabular}

Sumber : Data Marketing, 2017 (diolah) 
Pada Tabel 1 menunjukkan bahwa pada setiap tahun harga rata-rata penjulan buku yang ditetapkan perusahaan berbeda-beda, naik turunnya tingkat harga ditentukan berdasarkan pertimbangan tertentu yaitu karena adanya kenaikan bahan baku produksi, kenaikan harga eceran tertinggi (HET) yang ditetapkan pemerintah terutama pada produkproduk buku pemerintah juga banyaknya permintaan di pasar. Penetapan harga jual ditetapkan oleh bagian pemasar dengan persetujuan manajer pemasar. Sedangkan, target penjualan perusahaan pada setiap tahunnya ditetapkan oleh pemegang saham berdasarkan berbagai pertimbangan seperti keinginan pendapatan perusahaan yang besar, adanya rencana pasar yang akan dituju. Namun pada realisasi penjualan menunjukkan hasil pendapatan mengalami fluktuatif. Pendapatan tertinggi selama 5 tahun terakhir yaitu tahun 2012 dengan pendapatan customer sebesar 674 customer dengan tingkat ketercapaian penjualan $127 \%$ dari target, hal tersebut karena perusahaan pada saat itu mendapatkan tender pemerintah yaitu buku pelajaran tingkat nasional sebanyak empat propinsi sehingga menjadikan perusahaan tersebut sebagai perusahaan terbaik seIndonesia versi All Print Indonesia. Adapun pendapatan perusahaan paling rendah yaitu pada tahun 2015 sebanyak 549 customer dan realisasi penjualan sebesar $50 \%$, hal tersebut dikarenakan pada tahun 2015 kurangnya pengadaan tender dari pemerintah sehingga perusahaan hanya mendapat order dari perusahaan-perusahaan swasta sehingga mengakibatkan penurunan pendapatan. Tabel tersebut juga menjelaskan mengenai data keterlambatan produk sering mengalami naik turun. Hal tersebut dikarenakan beberapa faktor internal dan eksternal. Faktor internal meliputi pesanan produk pada musim ramai sehingga perusahaan mengalami kekurangan kapasitas mesin produksi yang mengakibatkan keterlambatan, keterbatasan armada pengiriman yang dimiliki perusahaan dan mahalnya biaya sewa armada dari luar. Sedangkan, faktor eksternal sendiri yaitu karena terjadinya kemacetan lalu lintas pada saat pengiriman khususnya untuk luar kota. Sedangkan data produk yang dikembalikan oleh konsumen kepada perusahaan, dikarenakan beberapa faktor seperti produk cacat, packing produk yang kurang rapi, produk kurang sesuai, warna tidak konsisten, lem kurang kuat sehingga customer mengembalikan produk. Pada tabel di atas menunjukkan pula tingkat pengembalian produk paling banyak yaitu pada tahun 2015 sebesar $11 \%$ dari produksi yaitu dikarenakan pekerjaan produksi pada tahun itu rata-rata dari perusahaan swasta dan memiliki tingkat kesulitan dibanding pekerjaan pemerintah sehingga banyak buku yang tidak terkontrol dan dikembalikan.

Upaya mewujudkan keberhasilan perusahaan perlu adanya manajemen pemasaran yang handal sehingga perusahaan dapat mencapai target penjualan. Adapun kegiatan pemasaran yang dilakukan PT Balebat Dedikasi Prima pada lima tahun terakhir yaitu yaitu sebagai berikut:

Tabel 2. Data Promosi yang dilakukan Perusahaan Periode 2012 - 2016

\begin{tabular}{cl}
\hline Tahun & \multicolumn{1}{c}{ Jenis-Jenis Promosi Yang di Berikan Pada Pelanggan } \\
\hline 2012 & Tender, Banner, Brosur. \\
2013 & Company profile, Brosur. \\
2014 & Company profile, banner, Brosur, Fliyer \\
2015 & Tender, Company profile, Banner, Brosur, Fliyer. \\
& Tender, Company profile, Banner, Brosur, Fliyer, Vidio profil, Iklan. \\
\hline
\end{tabular}

Sumber : Data Marketing, 2017 (diolah) 
Tabel 2 menginformasikan bahwa pada setiap tahun cara yang dilakukan bagian pemasar berbeda-beda tergantung dari kebutuhan dari masyarakat atau pelanggan di pasar. Tahun 2012 perusahaan menggunakan promosi tender untuk pemerintahan, banner dan brosur yang disebarkan ke sekolah dan instansi swasta, semakin berkembangnya zaman pada 2013 perusahaan menggunakan company profile karena pada tahun tersebut saham PT.Balebat Dedikasi Prima sudah seratus persen dibawah naungan PT. Telkom Indonesia, lalu untuk menarik calon konsumen pada tahun 2016 promosi pemasaran dilakukan melalui video profile yang dipublikasikan di youtube, instansi pemerintah melalui LPSE (Layanan Pengadaan Secara Elektronik) dan LKPP ( Lembaga Kebijakan Pengadaan Barang/Jasa Pemerintah) sehingga calon konsumen dengan mudah dapat melihat gambaran perusahaan secara visual tanpa harus melakukan kunjungan industri. Dengan persaingan yang semakin ketat mendorong perusahaan untuk dapat bersaing secara global sehingga tujuan perusahaan dapat terwujud. Adapun tujuan PT Balebat adalah menjadi perusahaan terbaik dan menjadi pemimpin pasar .Beberapa strategi yang perlu dilakukan adalah mengukur peran produk, penetapan harga saluran promosi dan saluran distribusi pada perusahaan. Berdasarkan paparan di atas, sangat penting dilakukan sebuah penelitian dengan judul 'Pengaruh Bauran Pemasaran terhadap Keputusan Pembelian pada Percetakan PT Balebat Dedikasi Prima, Bogor".

\section{MATERI DAN METODE}

\section{Bauran Pemasaran}

Pemasaran mempunyai fungsi yang amat penting dalam mencapai keberhasilan perusahaan. Dalam mencapai keberhasilan pemasaran, setiap perusahaan perlu menyusun strategi pemasaran dengan mengkombinasikan elemen-elemen dalam bauran pemasaran. Dalam bauran pemasaran terdapat variabelvariabel yang saling mendukung yang tidak dapat dipisahkan satu sama lainnya, yang kemudian oleh perusahaaan digabungkan untuk memperoleh tanggapan-tanggapan yang diinginkan di dalam pasar sasaran.

Menurut Kotler dan Amstrong (2012;75), Marketing mix is the set of tactical marketing tolls that the firm blends to produce the response it wants in the target market. Bauran pemasaran merupakan seperangkat alat pemasaran yang digunakan perusahaan untuk secara terus menerus untuk mencapai tujuan perusahaan di pasar sasaran.

Adapun menurut Assauri (2013;12), bauran pemasaran sekumpulan keputusan tentang harga, produk, saluran distribusi, manajemen hubungan pelanggan yang merupakan implementasi dari strategi pemasaran.

Dari uraian di atas dapat disimpulkan bahwa bauran pemasaran merupakan unsurunsur pemasaran yang saling terkait, sehingga perusahaan dapat mencapai tujuan pemasaran yang efektif, sekaligus memuaskan kebutuhan dan keinginan konsumen. Komponen Bauran pemasaran menurut Kolter dan Amstrong adalah sebagai berikut :

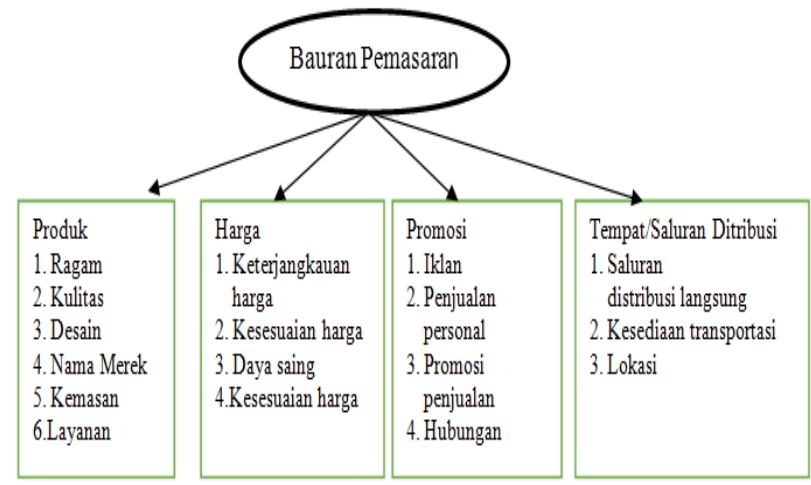

Gambar 1. Komponen Bauran Pemasaran Sumber : Kotler dan Amstrong (2012 :47)

\section{Produk}


Menurut Assauri (2012;118), produk merupakan kemasan total dari manfaat yang diciptakan atau diberikan oleh suatu organisasi untuk ditawarkan kepada pemakai sasaran.

\section{Harga}

Harga yaitu kewajiban berupa nilai bagi konsumen, yang harus dibayar guna mendapatkan dan menikmati suatu barang atau jasa, termasuk biaya keuangan dari konsumsi, di samping biaya sosial yang bukan keuangan, seperti dalam bentuk waktu, upaya, psikis, risiko dan prestise atau gengsi sosial (Kotler dan Keller, 2009;68).

\section{Promosi}

Promosi menurut Swastha dan Irawan (2005:349) yaitu memberikan sumber informasi guna mengarahkan calon konsumen berupa orang maupun organisasi untuk mengarahkan pada pemasaran.

\section{Distribusi}

Adapun menurut Tjiptono (2008;187) saluran pendistribusian produk baik barang maupun berupa jasa dijelaskan sebagai langkah pemasaran bertujuan agar penyampaian lebih mudah dari produsen kepada konsumen .

\section{Keputusan Pembelian}

Pemasar dalam mencapai keberhasilan harus melewati bermacam-macam pengaruh pembeli dan mengembangkan pemahaman mengenai bagaimana konsumen melakukan keputusan pembelian. Menurut Tjiptono (2012;199), pengambilan keputusan konsumen merupakan salah satu aspek yang penting di dalam pemasaran karena konsumen akan melakukan pembelian atau tidak melakukan pembelian berdasarkan keputusan yang mereka tetapkan.

Adapun menurut Kotler dan Armstrong (2012:157), Consumer buyer behavior refers to the buying behavior of final consumers individuals and households that buy goods and services for personal consumptio, pengertian tersebut dapat diartikan bahwa perilaku keputusan pembelian mengacu pada perilaku pembelian akhir dari konsumen, baik individual, maupun rumah tangga yang membeli barang dan jasa untuk konsumsi pribadi.

\section{Kerangka Pemikiran}

Bauran Pemasaran merupakan salah satu komponen yang sangat penting dalam menentukan keberhasilan perusahaan. Dalam proses pengambilan keputusan pembelian atau pemilihan produk, seorang konsumen akan dipengaruhi oleh beberapa factor dalam bauran pemasaran. Hal-hal yang harus di lakukan perusahaan adalah sebagai berikut :

1. Produk yang dihasilkan perusahaan percetakan harus memiliki hasil kualitas yang sesuai standar, tinta dan kertas yang digunakan aman juga sesuai.

2. Harga yang ditawarkan terjangkau dan seimbang serta bersaing dengan pasar kompetitornya.

3. Promosi dilalukan oleh tenaga pemasar yang handal sehingga mampu memberikan rasa percaya bagi calon konsumen untuk menggunakan jasa percetakan perusahaan.

4. Pendistribusian yang tepat waktu dan jaminan pesanan produk percetakan sampai pada konsumen sangat perlu diperhatikan perusahaan percetakan. Karangka pemikiran dapat dilihat pada gambar berikut ini :

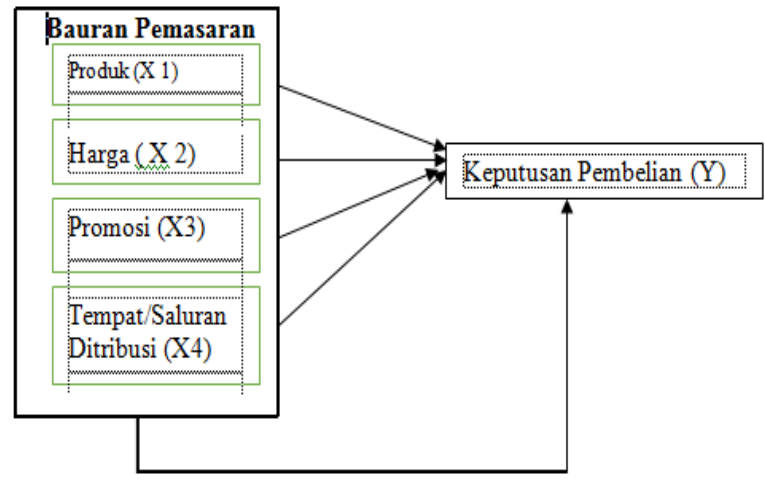

Gambar 2. Kerangka Pemikiran Yang Dikembangkan Sumber: Abdullah (2012)

\section{Desain Penelitian}

Pendekatan penelitian yang akan digunakan dalam penelitian ini adalah metode 
deskriptif dan asosiatif, karena adanya variabel-variabel yang akan ditelaah hubungannya serta tujuannya untuk menyajikan gambaran secara terstruktur, faktual, dan akurat mengenai fakta-fakta serta hubungan antar variabel yang diteliti.

\section{Populasi, Sampel}

Di dalam pengambilan sampel digunakan probability sampling. Menurut Sugiyono (2014: 60) yaitu teknik yang memberikan kesempatan/peluang yang sama pada setiap unsur maupun anggota didalam sebuah populasi yang nantinya akan dijadikan sebagai sampel. Jumlah sampel menggunakan rumus Slovin dikutip oleh Umar (2005) yang ditentukan oleh penulis dengan persentase kelonggaran ketidak telitian 10\%. Berdasarkan hasil perhitungan diperoleh jumlah sampel sebanyak 100 sampel (Pembulatan ukuran sampel dari 89,9 menjadi 100 orang dengan pertimbangan agar mendapat data yang lebih akurat.

\section{Operasional Variabel}

Penelitian ini terdiri dari variabel bebas (independent variable) diantaranya produk $\left(\mathrm{X}_{1}\right)$, harga $\left(\mathrm{X}_{2}\right)$, promosi $\left(\mathrm{X}_{3}\right)$, saluran distribusi $\left(\mathrm{X}_{4}\right)$ dan variable terikat (dependent variable) serta keputusan pembelian (Y). Adapun operasional variabel adalah sebagai berikut :

\section{Tabel 3. Operasional Variabel dan Indikator}

\begin{tabular}{|c|c|c|c|}
\hline Variabel & Definisi & Indikator & Sloala ulaur \\
\hline $\begin{array}{l}1 \text { Produk } \\
\text { ( X 1) }\end{array}$ & $\begin{array}{l}\text { Produk yaitusegala jenis yang bisa } \\
\text { memem hi bebutuhan manusia } \\
\text { baik yang terwujud ataupun yang } \\
\text { tidak terwujud. } \\
\text { Kotler dan Amstrong ( } 2012: 52)\end{array}$ & $\begin{array}{l}\text { 1. Keragaman } \\
\text { 2. Kualitas } \\
\text { 3. Desain } \\
\text { 4. Nama Merek } \\
\text { 5. Kemasan } \\
\text { 6. Layanan }\end{array}$ & $\begin{array}{c}\text { Ordinal, } \\
\text { Likert }(1-5)\end{array}$ \\
\hline $\begin{array}{l}2 \text { Harga } \\
(\mathrm{X} 2)\end{array}$ & $\begin{array}{l}\text { Harga adalah sejumlah nilai tvlar } \\
\text { untsk menggunakan produk } \\
\text { maupun jas a berdasarkan manfaat } \\
\text { yang diterimanya. } \\
\text { Kotlex dan Amstrong ( } 2012: 278)\end{array}$ & $\begin{array}{l}\text { 1. Keterjangkavan } \\
\text { 2. Kesesuaian dengan laulitas } \\
\text { 3. Daya saing } \\
\text { 4. Kesesuaian dengan } \\
\text { manfaat }\end{array}$ & $\begin{array}{c}\text { Ordinal, } \\
\text { Likert }(1-5)\end{array}$ \\
\hline $\begin{array}{l}3 \text { Promosi } \\
\text { (X3) }\end{array}$ & $\begin{array}{l}\text { Promosi cara menginformasikan } \\
\text { manfaat dan kegunaan suatu } \\
\text { produk ma vpun berupa jasa pada } \\
\text { individu ataupun oranisasi. } \\
\text { Kotler dan Amstrong ( } 2012: 52)\end{array}$ & $\begin{array}{l}\text { 1. Ikian } \\
\text { 2. Penjualan personal } \\
\text { 3. Promosi penjualan } \\
\text { 4. Hubung anmasyarakat }\end{array}$ & $\begin{array}{c}\text { Ordinal, } \\
\text { Likert (1-5) }\end{array}$ \\
\hline $\begin{array}{l}\text { 4.Tempat' } \\
\text { Saluran } \\
\text { Distribusi } \\
\text { (X4) }\end{array}$ & $\begin{array}{l}\text { Salviran distribusi yang ditujukan } \\
\text { untuk mencapai target konsumen. } \\
\text { Deng an sis tem ini mencalap } \\
\text { lokasi, transportasi, pergudangan } \\
\text { dan sebag airnya } \\
\text { Sumber: Kotler dan Amstrong } \\
\text { (2012 }\end{array}$ & $\begin{array}{l}\text { Tempat/Saluran Ditribusi } \\
\text { (X3) } \\
\text { 1. Sa hran secaralangsung } \\
\text { 2. Ketersediaan transportasi } \\
\text { 3. Lokcasi } \\
\text { 4. Calapan distribusi }\end{array}$ & $\begin{array}{c}\text { Ordinal, } \\
\text { Likert (1-5) }\end{array}$ \\
\hline $\begin{array}{l}\text { 5. Keputusan } \\
\text { Pembelian } \\
\text { (Y) }\end{array}$ & $\begin{array}{l}\text { Tindakan dari konsumen bersedia } \\
\text { membeli atavpun tidak pada suatu } \\
\text { produk atav mavpun jasa } \\
\text { Kotler dan Amstrong ( } 2012: 52)\end{array}$ & $\begin{array}{l}\text { 1. Konsumen senang } \\
\text { 2. Bersedia membeli lagi } \\
\text { 3. Pilihan dalam transalcsi } \\
\text { yang tepat } \\
\text { 4.Merelcomend asikan kepada } \\
\text { orang lain }\end{array}$ & $\begin{array}{c}\text { Ordinal, } \\
\text { Likert }(1-5)\end{array}$ \\
\hline
\end{tabular}

Sumber : Data Kueisioner 2017

\section{Metode Pengumpulan Data}


Data yang dipergunakan adalah data primer dan sekunder. Data primer ialah data yang diperoleh melalui pemberian angket pertanyaan tertulis (kuesioner) secara langsung pada responden. Data sekunder yaitu data yang sudah selesai diolah lebih lanjut sehingga lebih informatif untuk pihak lain melalui studi kepustakaan, studi lapangan, observasi, wawancara dan kuesioner. Untuk mengetahui penilaian responden dalam kuesioner menggunakan skala likert 5 point . Pengolahan data hasil kuesioner menurut Sugiono (2014:291) dapat diukur menggunakan skala likert dari skala ordinal satu sampai lima.

\section{Metode Pengujian Data Instrumen}

Untuk pengolahan data digunakan SPSS versi 22.0.Untuk mendapatkan data yang akurat perlu di uji validitas dengan tolak ukur berdasarkan pada nilai $r_{\text {hitung }} \geq r_{\text {tabel }}$ sebesar $0,3, \alpha=0,05$. Jika diperoleh angka $r_{\text {hitung }} \geq$ $\mathrm{r}_{\text {tabel}}$, maka item dianggap data valid berlaku sebaliknya. Lalu menggunakan pengujian reliabilitas, tolak ukurnya mempergunakan rumus Cronbach Alpha, dengan nilai ukur $r_{\text {hitung }} \geq \mathrm{r}_{\text {tabel }}(0,6)$, sehingga item bersangkutan dianggap reliabel begitupun sebaliknya.

\section{Uji Asumsi Klasik}

Untuk memperoleh gambaran hubungan variable secara parsial dan simultan sebelum dilakukan uji linear berganda mensyaratkan untuk dilakukan uji asumsi klasik agar diperoleh hasil terbaik. Menurut Damodar Gujarati (2012: 201) asumsi klasik digunakan agar model regresi cukup tidak bias. Uji asumsi klasik yang digunakan adalah :

1. Uji ini dimaksudkan untuk mengetahui normalitas data yang digunakan dari populasi yang berdistribusi normal. Menurut Ghozali (2011 : 209), uji normalitas bertujuan untuk menguji apakah dalam model regresi, variabel pengganggu atau residual memiliki distribusi normal, bila asumsi ini dilanggar maka uji statistik menjadi cukup tidak valid untuk jumlah sampel kecil. Uji normalitas data dilakukan dengan metode grafik Histogram dan Normal Probability Plots .Jika hasil data yang distribusinya normal dijelaskan dengan garis (titik-titik) yang mengikuti garis normal.

2. Uji Multikolinieritas, dikatakan tidak terjadi multikolinieritas ketika nilai Tolerance $>0,05$ atau VIF $<5$, dikarenakan model regresi linier berganda tidak terjadi gejala multikolinieritas.

3. Uji heteroskedastisitas menggunakan scatter plot. Scatter plot yang menyatakan ketika adanya titik-titik yang tersebar secara acak, hal ini menandakan tidak terjadinya heterokedastisitas.

\section{Metode Analisis Data}

Penelitian menggunakan regresi linier berganda. Menurut Sugiyono (2014:277) persamaan regresi linier berganda yang ditetapkan pada rumus :

$$
Y=a+\beta_{1} X_{1}+\beta_{2} X_{2}+\beta_{3} X_{3}+\beta_{4} X_{4}+\varepsilon
$$

Keterangan

Y = Variabel dependen keputusan pembelian produk percetakan

$\mathrm{A}=$ Bilangan Konstanta

$\mathrm{X}_{1}=$ Produk

$\mathrm{X}_{2}=$ Harga

$\mathrm{X}_{3}=$ Promosi

$\mathrm{X}_{4}=$ Distribusi

$\beta_{1}=$ Koefisien regresi variabel Produk

$\beta_{2}=$ Koefisien regresi variabel Harga

$\beta_{3}=$ Koefisien regresi variabel Promosi

$\beta_{4}=$ Koefisien regresi variabel Distribusi

\section{Analisis Korelasi Berganda}

Menurut Sugiyono (2016:205) korelasi ganda (multiple correlation) merupakan angka yang menunjukan arah dan kuatnya hubungan antara dua variabel independen secara bersama-sama atau lebih dengan satu variabel dependen. 
Agar dapat memberi penafsiran korelasi tersebut nilai yang sudah ditetapkan kecil atau besarnya, maka bisa berpedoman pada tabel hasil analisis korelasi nilai $r$ yang diuraikan pada tabel berikut :

\section{Tabel 4. Pedoman Interprestasi Koefesien Korelasi}

\begin{tabular}{c|c}
\hline Interval Nilai r & Interpretasi \\
\hline $0,00-0,199$ & Sangat Lemah \\
$0,20-0,399$ & Rendah \\
$0,40-0,599$ & Sedang \\
$0,60-0,799$ & Kuat \\
$0,80-1,000$ & Sangat Kuat \\
\hline
\end{tabular}

Sumber : Sugiyono, 2016

\section{Analisis Determinasi}

Menurut Priyatno (2012:207) analisis koefisien determinasi digunakan untuk mengetahui persentase penambahan pengaruh dari variabel independen secara bersama-sama variabel dependen dengan rumus sebagai berikut:

$$
\mathrm{KD}=r^{2} \times 100 \%
$$

keterangan:

$$
\begin{aligned}
\mathrm{KD} & =\text { koefisien determinasi } \\
r & =\text { koefisien korelasi }
\end{aligned}
$$

\section{Uji Hipotesis}

Pengujian ini menggunakan distribusi t, dengan keyakinan (1- $\alpha$ ) sebesar 95\% dengan derajat kebebasan sebesar n-5-1 untuk menguji hipotesis diterima atau ditolak menurut Priyatno (2012:139) digunakan uji F dan Uji-t: 1. Uji $F$ dengan kriteria keputusan uji $F$ sebagai berikut :

Bila angka $F_{\text {hitung }}$ menunjukkan lebih kecil dari atau sama dengan $F_{\text {tabel }}\left(F_{\text {hitung }} \leq F_{\text {tabel }}\right)$ pada $\alpha=0,05$ maka Ho diterima dan Ha ditolak, variabel tidak memberikan pengaruh yang signifikan dan positif maupun sebaliknya.

\section{Tabel 6. Rekapitulasi Tanggapan Pelanggan Terhadap Bauran Pemasaran Jasa}

2. Uji t dengan kriteria bila $t_{\text {hitung }}$ lebih kecil dari atau sama dengan $t_{\text {tabel }}\left(t_{\text {hitung }} \leq t_{\text {tabel }}\right)$ pada $\alpha=0,05$ maka Ho diterima dan Ha ditolak, artinya buaran pemasaran variabel tidak memberikan pengaruh yang signifikan dan positif maupun sebaliknya.

\section{PEMBAHASAN}

Hasil penyebaran kuesioner terhadap 100 responden yang dijadikan sampel diperoleh gambaran umum tentang karakteristik responden adalah :

Tabel 5. Karakteristik Responden

\begin{tabular}{l|l|c:c|l}
\hline No & Kriteria Responden & $\begin{array}{c}\text { Jumlah } \\
\text { Responden } \\
(\text { Orang }\end{array}$ & $\begin{array}{c}\text { Persentase } \\
(\%)\end{array}$ & Keterangan \\
\hline 1 & Jenis Kelamin & 64 & 12 & Perempuan \\
\hline 2 & Umur & 33 & 22 & $30-39$ tahun \\
\hline 3 & Pekerjaan & 52 & 39 & Wiraswasta \\
\hline 4 & Pendapatan & 40 & 40 & Rp. $>10.000 .000$ \\
\hline 5 & Pendidikan & 49 & 49 & Diploma Sajana \\
\hline 6 & $\begin{array}{l}\text { Jumlah melakukan } \\
\text { pembelian }\end{array}$ & 39 & 39 & 3Kali \\
\hline
\end{tabular}

Sumber: Data kuesioner , 2017

Berdasarkan tabel di atas dapat dijelaskan untuk jenis kelamin terbanyak adalah perempuan, dan usia responden yaitu berusia antara 30-39 tahun, usia tersebut dikarenakan responden sudah bekerja atau mempunyai usaha sendiri, dan pekerjaan mayoritas yaitu sebagai wiraswasta, pada umumnya responden adalah pemilik industri penerbitan atau perusahaan, pendapatan responden terbanyak yaitu Rp.>10.000.000, untuk pendidikan mayoritas adalah diploma/sarjana yaitu karena rata-rata responden adalah masyarakat yang menjadi pemilik sebuah usaha atau mempunyai jabatan di perusahaannya, jumlah pembelian terbanyak yaitu 3 kali. 


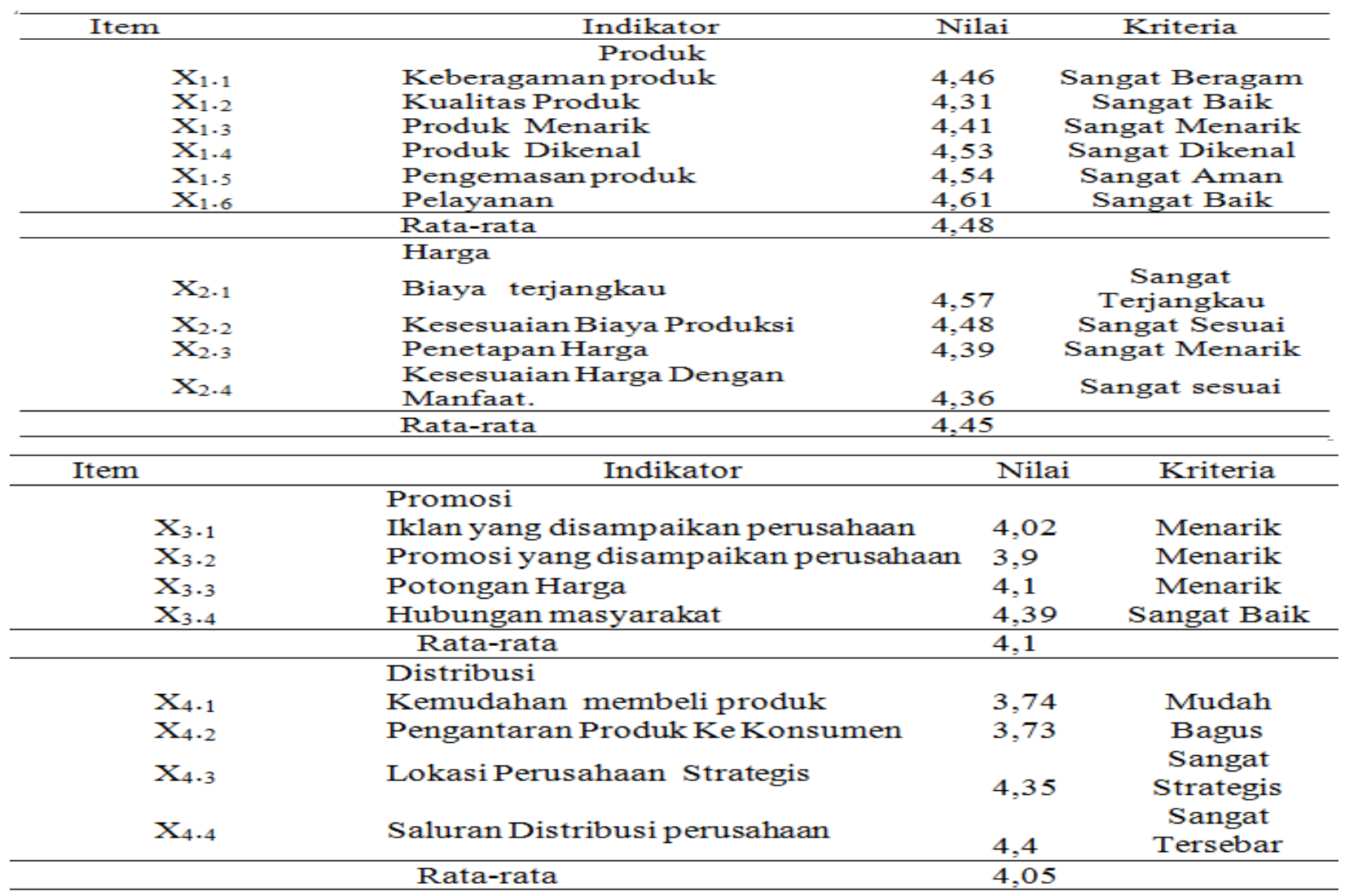

Sumber: Data primer diolah, 2017

Dari Tabel 6 memberikan kesimpulan diantaranya bahwa produk dengan nilai 4,48 dimana menurut responden produk perusahaan mempunyai keberagaman produk yang macam-macam seperti cetakan majalah, koran, buku pelajaran SD, SMP, SMK, universitas, leaflet, brosur sekolah, brosur indomaret, agenda bank, dan kalender. Untuk harga didapatkan angka sejumlah 4.45 dimana menunjukkan harga yang ditetapkan Balebat pada pelanggan sangat terjangkau dan bersaing dengan perusahaan sejenis di sekitar Balebat, manfaat produk yang diterima pelanggan sebanding dengan yang dibayar oleh pembeli. Pada pertanyaan mengenai promosi yang diberikan bagian pemasar, responden merasa perusahaan menyampaikan iklan yang sesuai dan biasanya dilakukan karyawan dengan cara mempresentasikan macam-macam produk, profil perusahaan, kemampuan perusahaan, pengalaman perusahaan, adapun hubungan yang dijalin dengan masyarakat sangat baik bisa berupa melakukan kegiatan gerak jalan, bagi-bagi buku pada sekolah terdekat ataupun bagi-bagi kalender dan agenda ke warga sekitar. Adapun untuk distribusi, tanggapan konsumen terhadap pendistribusian yang dilakukan perusahaan pengiriman produk mudah karena perusahaan selalu mengantar pesanan sampai pada tempat pemesan, dan produk mudah didapatkan, contohnya adalah cetakan buku pelajaran sekolah yang bisa di dapat di sekolah -sekolah yang bekerja sama dengan PT Balebat dan lokasi perusahaan yang strategis \pm 4 kilo meter dari tol Jagorawi sehingga pelanggan mudah menjangkau ke lokasi.

Tabel 7. Rekapitulasi Tanggapan Pelanggan Terhadap Keputusan Pembelian 


\begin{tabular}{c|l:c|l|}
\hline Item & \multicolumn{1}{|c|}{ Indikator } & Nilai & \multicolumn{1}{c|}{ Kriteria } \\
\hline$Y_{1}$ & Kepuasan Konsumen & 4,42 & Sangat Puas \\
\hline$Y_{2}$ & Konsistensipelanggan & 4,32 & Sangat Konsisten \\
$Y_{3}$ & Kepercayaan Konsumen & 4,32 & Sangat terpercaya \\
\hline$Y_{4}$ & Rekomendasi Konsumen & 3,4 & Direferensikan \\
\hline & Rata-×ata & 4,41 & \\
\hline
\end{tabular}

Sumber: Data primer diolah, 2017

Pada Rekapitulasi tanggapan pelanggan terhadap keputusan pembelian menunjukkan angka tertinggi adalah 4,42 dijelaskan bahwa pelanggan sangat puas dengan bauran pemasaran yang diterapkan perusahaan dan nilai terendah adalah rekomendasi konsumen didapatkan angka sebesar 3.4 yang artinya produk percetakan PT. Balebat direferensikan, tapi tidak semua pelanggan bersedia untuk merekomendasikan karena masih ada beberapa responden yang belum bersedia merekomendasikan pada konsumen lain.

\section{Hasil Estimasi Persamaan Regresi}

Bentuk persamaan pada hasil penelitian ini dihitung menggunakan analisis regresi berganda menggunakan SPSS 22, adapun hasil dari perhitunganya adalah:

Tabel 8. Rangkuman Hasil Perhitungan Analisis Regresi Linier Berganda

\begin{tabular}{|l|r|r|r|r|}
\hline Hasil Estimasi Persamaan Regresi & & & & \\
\hline Variabel & B & thitung & Sigt t & Beta \\
\hline Constant & .232 & 0,107 & .915 & \\
\hline Produk(X1) & .414 & 2,312 & .000 & .309 \\
\hline Harga (X2) & .190 & 3,411 & .001 & .237 \\
\hline Promosi(X3) & .152 & 2,308 & .023 & .161 \\
\hline Distribusi(X4) & .189 & 2,011 & .047 & .205 \\
\hline KeputusanPembelian(Y) & & & & \\
\hline t-tabel & 1986 & & & \\
\hline R & $.844^{2}$ & & F hitung & 58,578 \\
\hline R Square & .712 & & F hitung & 2,37 \\
\hline AdjustedR Squere & .699 & & Sigf & $.000^{b}$ \\
\hline
\end{tabular}

Sumber data kuesioner 2017

Dari data tersebut diperoleh persamaan regresi dengan model taksiran sebagai berikut:

$Y=0,232+0,414 X_{1}+0,190 X_{2}+0,152 X_{3}+0,189 X_{4}+\varepsilon$

Persamaan regresi berganda tersebut dijelaskan sebagai berikut:
1. koefisien $X_{1}$ dengan nilai positif 0,414 artinya jika semakin tinggi angka produk seperti kualitas produk, manfaat produk maka kepercayaan konsumen akan meningkat.

2. Koefisien $X_{2}=0,190$ artinya bahwa semakin tinggi angka dari harga seperti harga terjangkau, harga bersaing maka dapat menambah jumlah pembeli.

3. Koefisien $X_{3}=0,152$ artinya bahwa semakin tinggi nilai promosi seperti promosi tersampaikan, promosi menarik maka pelanggan akan merasa puas dan bersedia membeli produk.

4. Koefisien $\mathrm{X}_{4}=0,138$ artinya jika semakin tinggi nilai distribusi seperti pendistribusian tepat waktu maka menambah kepercayaan pelanggan untuk membeli produk.

Berdasarkan nilai $\mathrm{R}$ didapat sebesar 0,844 termasuk katagori sangat kuat $(0,8-1,00)$ artinya hubungan antara produk, harga, promosi dan distribusi terhadap keputusan pelanggan dalam pembelian produk sangat kuat. Adapun nilai R Square sebesar 0,712 yang artinya keputusan pembelian masyarakat $71,2 \%$ dijelaskan oleh unsur-unsur bauran pemasaran, dan 28,8\% dipengaruhi oleh variable-variabel diluar penelitian (bisa berupa bukti fisik, proses atau pengaruh social).

Uji secara simultan nilai $F_{\text {hitung }}$ sebesar 58,578 yang angkanya dikomparasikan dengan $\mathrm{F}_{\text {tabel, }}$ untuk mengetahui $\mathrm{F}_{\text {tabel }}$ maka perlu perhitungan menggunakan tingkat signifikasi sebesar 0,05 $(\alpha=5 \%)$ dengan angka derajat kebebasan $(\mathrm{dk}) \mathrm{n}-\mathrm{k}-1$ (100-5-1) $=94$. Dengan melihat hasil dari derajat kebebasan maka didapatkan nilai $\mathrm{F}_{\text {tabel }}$ sebesar 2,37 sehingga $F_{\text {hitung }}>F_{\text {tabel }}(58,578>2,37)$ dan memiliki nilai signifikansi $0,000<0,5$ maka Ho tidak diterima dan Ha diterima, yang artinya bauran pemasaran mempunyai pengaruh baik positif maupun signifikan pada keputusan pelanggan untuk membeli produk percetakan.

Dari hasil pengolahan data didapatkan nilai $t_{\text {hitung }}$ pada variabel produk $\left(\mathrm{X}_{1}\right)$ sebesar 
2,312 nilai $\mathrm{t}_{\text {tabel }}$ serta tingkat angka $\alpha=0,05$ yang diketahui derajat kebebasan n-k-1 maupun sama dengan angka 100-5-1=94 didapatkan nilai sebesar 1,986. Dengan demikian menunjukkan bahwa didapatkan angka $t_{\text {hitung }}$ lebih tinggi dari $t_{\text {tabel }}\left(t_{\text {hitung }}>t_{\text {tabel }}\right)$ sebesar $(2312>1,986)$, maka Ho tidak diterima dan Ha diterima artinya produk yang di hasilkan perusahaan mempunyai pengaruh baik secara positif maupun signifikan kepada suatu keputusan dari konsumen dalam pembelian produk percetakan.

Pada variabel harga memberikan kesimpulan ketika $\mathrm{t}_{\text {hitung }}$ pada variabel harga $\left(\mathrm{X}_{2}\right)$ sebesar 3,411 angka $\mathrm{t}_{\text {tabel }}$ dengan tingkat angka $\alpha=0,05$ dengan derajat kebebasan $\mathrm{n}-\mathrm{k}-$ 1 atau sama dengan 100-5-1=94 didapatkan nilai sebesar1,986. Hal ini menginformasikan bahwa angka $t_{\text {hitung }}$ yang didapatkan lebih tingggi dari angka $t_{\text {tabel }}$ yaitu sebesar $\left(t_{\text {hitung }}>t_{\text {tabel }}\right)$ sebesar $(3,411>1,986)$, maka Ho ditolak dan $\mathrm{H}_{\mathrm{a}}$ diterima, memberi pengertian harga yang ditetapkan perusahaan memberikan pengaruh yang positif dan juga signifikan terhadap keputusan pelanggan dalam membeli pada produk cetakan .

Pada variabel promosi memberi kesimpulan jika $t_{\text {hitung }}$ pada variabel promosi $\left(\mathrm{X}_{3}\right)$ sebesar 3,411 nilai tabel dengan tingkat $\alpha$ $=0,05$ dengan derajat kebebasan n-k-1 atau sama dengan 100-5-1=94 didapatkan angka sebesar 1,986. Hal ini menunjukkan angka $t_{\text {hitung }}$ yang di dapatkan lebih besar dari angka $t_{\text {tabel }}\left(t_{\text {hitung }}>t_{\text {tabel }}\right)$ yaitu sebesar $(2,308>1,986)$, maka Ho tidak diterima dan $\mathrm{Ha}$ diterima artinya promosi memberikan pengaruh yang positif dan secara signifikan terhadap keputusan pelanggan dalam membeli pada produk cetakan .

Pada variabel distribusi memberi kesimpulan bahwa $t_{\text {hitung pada variabel }}$ distribusi $\left(\mathrm{X}_{4}\right)$ sebesar 3,411 nilai $\mathrm{t}_{\text {tabel }}$ dengan tingkat $\alpha=0,05$ dengan derajat kebebasan $n-k-$ 1 atau sama dengan 100-5-1=94 didapatkan nilai sebesar 1,986. Hal ini menunjukkan angka $t_{\text {hitung }}$ yang didapatkan lebih besar dari angka $t_{\text {tabel }} \quad\left(t_{\text {hitung }}>t_{\text {tabel }}\right)$ yaitu sebesar $(2,011>1,986)$, maka Ho ditolak dan $\mathrm{Ha}$ diterima artinya distribusi mempunyai pengaruh secara positif juga signifikan pada keputusan pembelian produk cetakan yang dihasilkan dan dipasarkan oleh perusahaan percetakan.

\section{SIMPULAN DAN IMPLIKASI}

Berdasarkan hasil penelitian dan pembahasan maka penelitian ini dapat disimpulkan :

1. Tanggapan konsumen mengenai pengaruh bauran pemasaran terhadap keputusan pembelian yang mempunyai pengaruh tertinggi yaitu produk, kedua adalah harga, ketiga promosi dan terakhir adalah distribusi yang memberikan arti sebagai berikut:

a) Tanggapan konsumen terhadap variabel produk dengan nilai 4,48 memberi arti bahwa produk sangat berkualitas, sangat menarik, sangat beragam sangat disukai dan sangat bagus.

b) Tanggapan konsumen terhadap variabel harga, dengan nilai 4,45 yaitu harga produk mempunyai pengaruh percetakan sangat terjangkau, sangat sesuai dengan manfaat yang diberikan dan bersaing dengan produk percetakan sejenis.

c) Tanggapan konsumen terhadap promosi dengan nilai 4,39 menyatakan bahwa promosi yang dilakukan PT.Balebat Dedikasi Prima memiliki daya tarik yang kuat, dan promosi sangat terlibat dengan masyarakat dan konsumen.

d) Tanggapan konsumen terhadap distribusi sebesar 4.01 yaitu distribusi tepat waktu dan sangat bagus.

2. Bauran Pemasaran secara simultan berpengaruh positif dan signifikan terhadap keputusan pembelian.

3. Bauran Pemasaran (produk, harga, promosi dan distribusi) secara parsial berpengaruh 
positif dan signifikan terhadap keputusan pembelian.

Berdasarkan kesimpulan di atas, untuk meningkatkan keputusan pembelian, maka implikasi yang dapat disampaikan adalah :

a) Mempertahankan dan meningkatkan penerapan dari bauran pemasaran sehingga konsumen menjadi pelanggan yang konsisten dan setia untuk membeli produk percetakan PT. Balebat Dedikasi Prima.

b) Meningkatkan perbaikan dari variabel distribusi yaitu melalui penambahan armada perusahaan agar pengiriman produk perusahaan dapat dilakukan dengan tepat waktu.

c) Melakukan evaluasi secara berkala yang dilakukan oleh manajemen PT. Balebat Dedikasi Prima terkait bauran pemasaran terhadap keputusan pembelian dengan memberikan anget kepada konsumen.

d) Untuk penelitian selanjutnya perlu memperhatikan indikator lainnya dan alat analisis yang berbeda untuk mengetahui faktor yang mempengaruhi keputusan pembelian seperti bukti fisik, dan proses sehingga didapatkan hasil yang lebih mendukung.

\section{UCAPAN TERIMAKASIH}

Penulis mengucapkan terimakasih kepada seluruh karyawan PT. Balebat Dedikasi Prima dan juga kepada responden yang sudah berpartisipasi untuk menjawab dan mengisi kuesioner penelitian.

\section{DAFTAR PUSTAKA}

Alma, Buchari. 2014. Manajemen Pemasaran dan Pemasaran Jasa. Bandung. Alfabeta.

Assauri, Sofjan. 2012. Manajemen Pemasaran. Jakarta. Rajawali, Gramedia Pustaka Utama.

Basu Swastha dan Irawan, 2005. Asas-asas Marketing. Yogyakarta., Liberty :
Damodar N., Gujarati dan Dawn C. Porter. 2012. Dasar-dasar Ekonometrika. Jakarta. Buku 2. Edisi 5. Raden Carlos Mangunsong, Salemba Empat.

Kotler, Philip. \& Gary Armstrong. 2018. Prinsip-Prinsip Pemasaran. Jakarta. Edisi 12. Jilid 1. Erlangga.

Kevin Lane Keller. 2009. Manajemen Pemasaran. Jakarta. Jilid I. Edisi 13 Erlangga harmmesta. 2012, Manajemen Pemasaran. Jakarta. Jilid I. Edisi 12. Erlangga.

Swastha,Basu. 2010. Manajemen Penjualan Pelaksanaan Penjualan. Yogyakarta. BPFE.

Sugiono, 2014. Metode Penelitian Pendidikan Pendekatan Kuantitatif dan Kualitatif R\&D. Bandung: Alfabeta Suparyanto $\&$ Rosad. Manajemen Pemasaran. Bogor: IN MEDIA

Sugiono, 2014. Metode Penelitian Pendidikan Pendekatan Kuantitatif dan Kualitatif R\&D. Bandung. Alfabeta.

Sugiono $_{2}$,2016, Metode Penelitian Kuantitatif, Kualitatif, dan R\&D. Bandung. Alfabeta.

Tjiptono, Fandy, 2008, Strategi Pemasaran, Yogyakarta. Edisi 3, ANDI.

\section{Sumber Lain}

PT Balebat Dedikasi Prima

www.Blog.Wtakins.comwww.Alprin.com 